\title{
Comparative study between vaginal isosorbide mononitrate and misoprostol for induction of cervical ripening prior to surgical evacuation of first trimester embryonic demise
}

\author{
Amrit Pal Kaur Dhillon*, Harbhajan Kaur Shergill, Pawan Yadav
}

Department of Obstetrics \& Gynaecology, Government Medical College, Amritsar-143001, Punjab, India

Received: 01 February 2015

Accepted: 23 February 2015

*Correspondence:

Dr. Amrit Pal Kaur Dhillon,

E-mail: amritdhillon63@msn.com

Copyright: $\odot$ the author(s), publisher and licensee Medip Academy. This is an open-access article distributed under the terms of the Creative Commons Attribution Non-Commercial License, which permits unrestricted non-commercial use, distribution, and reproduction in any medium, provided the original work is properly cited.

\begin{abstract}
Background: Objective: To compare the efficacy \& safety of Nitric Oxide (NO) donor, isosorbide mononitrate (ISN) to that of misoprostol, applied vaginally as tablets for cervical ripening prior to suction evacuation of first trimester embryonic demise.

Methods: This is a prospective, randomized, double blind controlled trial conducted at tertiary level teaching hospital. 50 women with first trimester embryonic demise with closed cervix requiring suction evacuation were divided randomly into two groups of 25 women each. In group A, tab. isosorbide mononitrate $80 \mathrm{mg}$ and in group B, tab. misoprostol $400 \mu \mathrm{g}$ was applied vaginally. Both the drugs were repeated every three hourly up to a maximum of four doses or until reaching cervical dilation of $8 \mathrm{~mm}$. Cervical dilatation was assessed at baseline \& every three hours after each dose. A set of questionnaire was used for the appearance of side effects. Once $8 \mathrm{~mm}$ cervical dilatation achieved, suction evacuation was done. Total volume of blood lost at suction evacuation was measured.

Results: Frequency of doses, induction to ripening interval \& intra operative blood loss was significantly higher with isosorbide mononitrate as compared to misoprostol. Headache \& palpitation were main side effects of isosorbide mononitrate. The percentages of successful \& failed inductions were comparable in both the groups.

Conclusions: Misoprostol is better cervical dilator prior to suction evacuation in first trimester embryonic demise with minimal side effects which are acceptable to the patient.
\end{abstract}

Keywords: Isosorbide mononitrate, Misoprostol, Early pregnancy embryonic demise

\section{INTRODUCTION}

Early embryonic demise is a common obstetrical problem, upsetting the patient \& carries a small risk of coagulation defect if left untreated. Surgical management is the standard treatment but if done without prior cervical ripening is associated with complications. The term cervical ripening means thinning, softening and opening of the cervix. Various pharmacological \& non pharmacological methods are available for cervical ripening each having its own advantages \& disadvantages. Prostaglandins, especially PGE2, have for a long time been thought of as key mediators of cervical ripening by causing dilatation of cervical vessels and extravasation of leucocytes. ${ }^{1}$ Isosorbide mononitrate, a nitric oxide donor, promote cervical smooth muscle relaxation in early pregnancy as well as term and has been applied clinically as cervical ripening agents. Cervical priming using prostaglandins or nitric oxide donors prior to surgical evacuation reduces operative time, blood loss \& promotes easier mechanical dilatation. $^{2}$ According to RCOG guidelines, cervical 
priming is beneficial prior to surgical abortion \& should be routinely used in women below 18 years of age and in women beyond the $10^{\text {th }}$ gestational week. ${ }^{3}$

\section{METHODS}

The present randomized, double blind controlled study was conducted on 50 subjects admitted in a tertiary care hospital over a period of two years after taking permission from the institutional ethics committee \& informed written consent from the patients. The eligibility criteria were first trimester embryonic demise with cervical internal os closed. The patients were excluded from the study if they had bleeding per vaginum, process of expulsion already started, any associated medical disorder or history of hypersensitivity to these drugs. All patients were evaluated by detailed history, general physical examination, pelvic examination, pelvic ultrasound, vital baseline parameters. Relevant hematological investigations were done.

The participants were randomly allocated into two groups of 25 subjects each. In group $A$, tab. isosorbide mononitrate $80 \mathrm{mg}$ was placed in posterior vaginal fornix $\&$ dose was repeated every three hourly up to a maximum of four doses or until reaching cervical dilatation $>8 \mathrm{~mm}$. The maximum dose was $320 \mathrm{mg}$. In group B, tab. misoprostol $400 \mu \mathrm{g}$ was placed in posterior vaginal fornix $\&$ dose was repeated three hourly, up to a maximum of four doses or until reaching cervical dilatation of $>8 \mathrm{~mm}$. The maximum dose was $1600 \mu \mathrm{g}$. Cervical dilatation was assessed by passing Hegar dilator of greatest diameter that could be passed through internal os at baseline \& every three hourly before placement of the next dose. Vital parameters were assessed at intervals. The participants were asked to respond to a questionnaire regarding side effects. Suction evacuation of products of conception was done when cervical dilatation of $8 \mathrm{~mm}$ was achieved. Total volume of blood lost was measured. Lack of cervical dilatation of $8 \mathrm{~mm}$ after fourth dose was taken as failure.

\section{RESULTS}

Mean age of subjects in both the groups was comparable being $25.52 \pm 3.02$ years, \& $25.68 \pm 3.06$ years in isosorbide mononitrate and misoprostol group respectively. The distribution of subjects on the basis of parity \& gestational age at which embryonic demise occurred was also comparable in both the groups.

The highest frequency of dosage used in ISN group was three doses in $9(36 \%)$ subjects, followed by two \& four doses in $6(24 \%)$ subjects each. Only four (16\%) subjects used single dose (Table1). In misoprostol group, 12 $(48 \%)$ subjects achieved required cervical dilatation after single dose of misoprostol, followed by two doses in eight $(32 \%)$, Three doses in three (12\%) subjects. Only two $(8 \%)$ subjects required four doses. The difference was highly significant. $(\mathrm{P}=0.026)$.
Table 1: Distribution of doses in study groups.

\begin{tabular}{|c|c|c|c|c|c|c|}
\hline \multirow[t]{2}{*}{$\begin{array}{l}\text { No. of } \\
\text { doses }\end{array}$} & \multicolumn{2}{|c|}{$\begin{array}{l}\text { Group A } \\
(\mathrm{n}=25) \\
\text { tab. ISN }\end{array}$} & \multicolumn{2}{|c|}{$\begin{array}{l}\text { Group B ( } n=25) \\
\text { tab. misoprostol }\end{array}$} & \multicolumn{2}{|c|}{ Total } \\
\hline & No. & $\%$ age & No. & \%age & No. & $\%$ age \\
\hline 1 & 4 & 16.0 & 12 & 48.0 & 16 & 32.0 \\
\hline 2 & 6 & 24.0 & 8 & 32.0 & 14 & 28.0 \\
\hline 3 & 9 & 36.0 & 3 & 12.0 & 12 & 24.0 \\
\hline 4 & 6 & 24.0 & 2 & 8.0 & 8 & 16.0 \\
\hline Total & 25 & 100.0 & 25 & 100.0 & 50 & 100.0 \\
\hline
\end{tabular}

$X^{2}=9.286 ; \mathrm{df}=3 ; \mathrm{P}=0.026(\mathrm{P}<0.05$ Significant $)$

The frequency of dosage was significantly higher in tab. isosorbide mononitrate (Group A) than in tab. misoprostol (Group B).

Induction to ripening interval was significantly higher in ISN group as compared to misoprostol group $(\mathrm{P}=0.041)$ (Table 2). The mean induction to ripening interval in ISN group was $7.50 \pm 2.89$ hours which is significantly higher than that in misoprostol group which was $5.08 \pm 2.67$ hours (Table 3).

Table 2: Induction to ripening interval in hours.

\begin{tabular}{|c|c|c|c|}
\hline Drug used & $\begin{array}{l}\text { Induction } \\
\text { to ripening } \\
\text { interval } \\
\text { (hours) }\end{array}$ & $\begin{array}{l}\text { No. of } \\
\text { patients }\end{array}$ & $\%$ age \\
\hline \multirow{6}{*}{$\begin{array}{l}\text { Group A } \\
\text { Tab. isosorbide } \\
\text { mononitrate } \\
(n=25)\end{array}$} & No effect & 5 & 20.0 \\
\hline & 3 & 4 & 16.0 \\
\hline & 6 & 6 & 24.0 \\
\hline & 9 & 9 & 36.0 \\
\hline & 12 & 1 & 4.0 \\
\hline & Total & 25 & 100.0 \\
\hline \multirow{6}{*}{$\begin{array}{l}\text { Group B } \\
\text { Tab. misoprostol } \\
(n=25)\end{array}$} & No effect & 1 & 4.0 \\
\hline & 3 & 12 & 48.0 \\
\hline & 6 & 8 & 32.0 \\
\hline & 9 & 3 & 12.0 \\
\hline & 12 & 1 & 4.0 \\
\hline & Total & 25 & 100.0 \\
\hline
\end{tabular}

$X^{2}=9.952 ; d f=4 ; P=0.041(P<0.05$ Significant $)$

Table 3: Mean induction to ripening interval (hours).

\begin{tabular}{|l|lll|}
\hline Drug group & $\begin{array}{l}\text { Mean interval } \\
\text { (hours) } \pm \mathrm{SD}\end{array}$ & $\mathrm{t}$ value & $\mathrm{P}$ value \\
\hline $\begin{array}{l}\text { ISN group A } \\
(\mathrm{N}=25)\end{array}$ & $7.50 \pm 2.891$ & & \\
\hline $\begin{array}{l}\text { Misoprostol } \\
\text { group B }(\mathrm{N}=25)\end{array}$ & $5.08 \pm 2.669$ & & 0.048 \\
\hline
\end{tabular}

Mean induction ripening interval significantly higher in isosorbide mononitrate group. 
Mean intra operative blood loss in ISN group was 226.80 $\pm 30.23 \mathrm{ml} \&$ in misoprostol group it was $146.00 \pm 16.07$ $\mathrm{ml}$ (Table 4).

There is no significant difference in the need of uterotonic agent in both the groups (Table 5).

A significant higher number of women in ISN group experienced headache (Figure 1).

The number of failed inductions were non significantly higher in ISN group (Figure 2).
Table 4: Mean intraoperative blood loss ( $\mathrm{ml})$ in study groups.

\begin{tabular}{|lllll|} 
& $\begin{array}{c}\text { Group A } \\
(\mathrm{n}=25)\end{array}$ & $\begin{array}{l}\text { Group B } \\
(\mathrm{n}=25)\end{array}$ & $\begin{array}{l}\mathrm{t} \\
\text { value }\end{array}$ & $\begin{array}{l}\mathrm{P} \\
\text { value }\end{array}$ \\
\begin{tabular}{|l} 
Mean \\
intra- \\
operative \\
blood \\
loss $(\mathrm{ml})$
\end{tabular} & $226.80 \pm 30.23$ & $146.00 \pm 16.07$ & 11.80 & $<0.001$ \\
\hline
\end{tabular}

Intra operative blood loss was significantly higher in tab. isosorbide mononitrate (Group A) than tab. misoprostol (Group B).

Table 5: Need for uterotonic agent in both study groups.

\begin{tabular}{|c|c|c|c|c|c|c|c|}
\hline & \multicolumn{2}{|c|}{$\begin{array}{l}\text { Group A } \\
(\mathrm{N}=25)\end{array}$} & \multicolumn{2}{|c|}{$\begin{array}{l}\text { Group B } \\
(\mathrm{N}=25)\end{array}$} & \multicolumn{2}{|l|}{ Total } & \multirow{2}{*}{$P$ value } \\
\hline & $\begin{array}{l}\text { No. of } \\
\text { cases }\end{array}$ & \%age & $\begin{array}{l}\text { No. of } \\
\text { cases }\end{array}$ & $\%$ age & $\begin{array}{l}\text { No. of } \\
\text { cases }\end{array}$ & \%age & \\
\hline No need & 20 & 80.0 & 21 & 84.0 & 41 & 82.0 & \multirow{3}{*}{$>0.05$} \\
\hline Need for uterotonic agent & 5 & 20.0 & 4 & 16 & 9 & 18.0 & \\
\hline Total & 25 & 100.0 & 25 & 100.0 & 50 & 100.0 & \\
\hline
\end{tabular}

$$
\mathrm{X}^{2}=0.136 ; \mathrm{df}=1 ; \mathrm{P}>0.05
$$

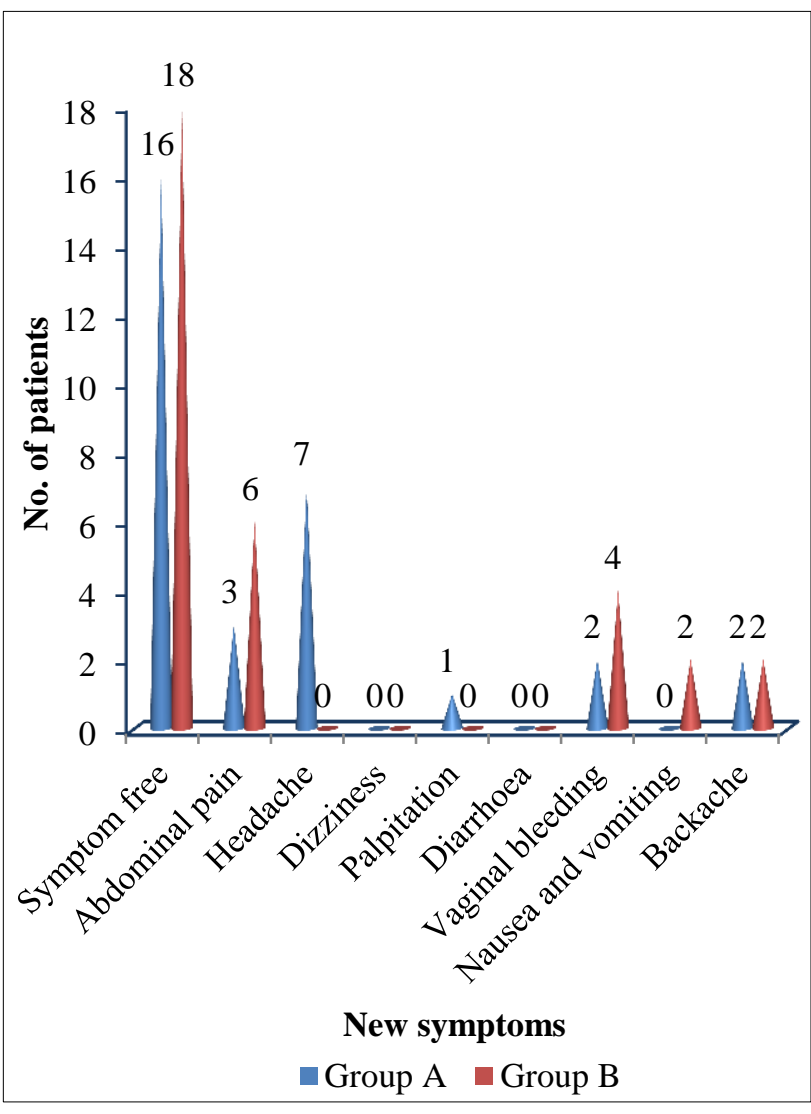

Figure 1: Showing incidence of each new symptom occurring after administration of cervical ripening agent in two groups.

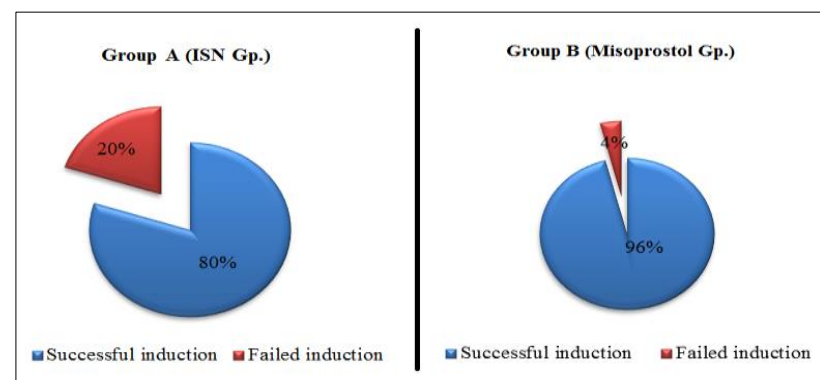

Figure 2: Percentage of successful \& failed inductions in both the groups.

\section{DISCUSSION}

Irrespective of previous obstetrical history, induction of pre surgical cervical ripening is required to reduce mechanical trauma to the cervix. ${ }^{3}$ Currently, pharmacological regimens are increasingly being used to dilate and soften the cervix making mechanical dilatation unnecessary. The present study showed more rapid cervical dilatation achieved with tab. misoprostol as compared to tab. isosorbide mononitrate. As the induction ripening interval was higher in ISN group so the frequency of dosage was also higher in this drug. The mean induction to ripening interval in ISN group (Group A) was $7.50 \pm 2.90$ hours while in misoprostol group (Group B) it was $5.08 \pm 2.67$ hours which was significantly high in group A. $20(80 \%)$ subjects achieved successful cervical dilatation while $5(20 \%)$ failed with tab. ISN. In contrast $24(96 \%)$ subjects achieved 
successful dilatation with tab. Misoprostol giving failure in only one subject (4\%). A study by Radulovic et al. found that tab. misoprostol induced a more pronounced canal ripening than tab. isosorbide mononitrate. Cervical resistance was significantly higher in patients treated with isosorbide mononitrate as compared to tab. misoprostol. ${ }^{4}$

Similarly Li CF et al. showed that tab misoprostol led to significantly higher cervical dilatation \& required less cumulative force than tab. ISN. ${ }^{5}$ A study conducted by Shafique et al. concluded that highest dose frequency in group A and group B was two doses \& single dose respectively, which was used in $32 \%$ \& $52 \%$ subjects respectively. The failure rates in group A was $16 \%$ \& group $\mathrm{B}$, it was $6 \%{ }^{6}$

Our study showed that there was no significant difference in the number of subjects who remained symptom free in both the groups. Headache was significantly higher with tab. Isosorbide mononitrate. Similar findings have been shown by Duhan $\mathrm{N}$ et al. ${ }^{7}$ Abdominal pain was non significantly higher after administration of misoprostol in present study in contrast to significant high incidence of pain (17 patients v/s 55 patients) seen by Waleed-EIKhayat et al. ${ }^{8}$ Vital parameters showed no significant variation in our study. Arteago-Troncoso G et al. ${ }^{9}$ showed that systolic \& diastolic blood pressures were lower after administration of tab. ISN than after prostaglandin analogues. The difference in mean systolic \& diastolic blood pressure was greatest at 3 hours with a difference of $7.7 \mathrm{mmHg}(\mathrm{P}<0.001)$ and $5.9 \mathrm{mmHg}(\mathrm{P}<0.003)$ respectively.

Ledingham MA et al. showed no advantage of combining misoprostol with isosorbide mononitrate over misoprostol alone for pre-operative cervical ripening in first trimester termination of pregnancy. ${ }^{10}$ The use of combination of misoprostol \& isosorbide mononitrate has been shown to be having higher side effects as greater proportion of women complained of headache in addition to their abdominal pain. ${ }^{10}$

The present study showed significant difference in mean blood loss in two groups similar to the findings of $\mathrm{Li} \mathrm{CF}$ et al., ${ }^{5}$ However Ledingham $\mathrm{MA}$ et al. found no difference in blood loss in both the groups. ${ }^{10}$

\section{CONCLUSION}

On the basis of the results we conclude that tablet misoprostol is a better cervical ripening agent with quicker response, less side effects, better acceptability, leading to early surgical evacuation and short hospital stay than tablet isosorbide mononitrate prior to suction evacuation of first trimester embryonic demise.

Funding: No funding sources

Conflict of interest: None declared

Ethical approval: The study was approved by the institutional ethics committee

\section{REFERENCES}

1. Winkler M, Rath W. Changes in cervical extracellular matrix during pregnancy and parturition. J Perinat Med. 1999;27:45-60.

2. Ekerhovd E, Weijdegard B, Brannstrom M, MattsbyBaltzer I, Norstrom A. Nitric Oxide induced cervical ripening in human. Am J Obstet Gynecol. 2002; $186: 745-50$.

3. RCOG. The care of women requesting induced abortion. In: RCOG, eds. Evidence Based Clinical Guideline Number 7. London: RCOG Press; 2004.

4. Radulovic NV, Norstrom A, Ekerhovd E. Outpatient cervical ripening before first trimester surgical abortion: a comparison between misoprostol and isosorbide mononitrate. Acta Obstet Gynecol Scand. 2007;86(3):344-8.

5. Li CFI, Chan CWC, Ho PC. A comparison of isosorbide mononitrate and misoprostol cervical ripening before suction evacuation. Obstet Gynecol. 2003;102:583-8.

6. Shafique U, Kazmi F, Rehana F. Vaginal isosorbide mononitrate and misoprostol for induction of cervical ripening prior to $1^{\text {st }}$ trimester surgical evacuation of retained products of conception. J Rawalpindi Med Coll (JRMC). 2010;14(2):101-3.

7. Duhan N, Gupta S, Dahia K, Sirohiwal D, Rohilla S. Comparison of isosorbide mononitrate and misoprostol for cervical ripening in termination of pregnancy between 8 and 12 weeks; a randomized controlled trial. Arch Gynecol Obstet. 2011;283:1245-8.

8. Waleed El-Khayat, Ahmed Maged, Hassan Omar. A comparative study between isosorbide mononitrate versus misoprostol prior to hysteroscopy. Middle East Fertil Soc J. 2010;15(4):278-80.

9. Arteaga-Troncoso G, Villegas-Alvarado A, BelmontGomez A, Martinez-Herrera FJ, Villagrana-Zesati R, Gurrera Infante F. Intracervical application of the nitric acid donor isosorbide dinitrate for induction of cervical ripening: a randomized controlled trial to determine clinical efficacy and safety prior to first trimester surgical evacuation of products of conception. BJOG. 2005;112:1615-9.

10. Ledingham MA, Thomson AJ, Lunan CB, Greer IA, Norman JE. A comparison of isosorbide mononitrate, misoprostol and combination therapy for first trimester pre-operative cervical ripening: a randomized controlled trial. Br J Obstet Gynecol. 2001;108:276-8.

DOI: $10.5455 / 2320-1770$. ijrcog20150422

Cite this article as: Dhillon APK, Shergill HK, Yadav P. Comparative study between vaginal isosorbide mononitrate and misoprostol for induction of cervical ripening prior to surgical evacuation of first trimester embryonic demise. Int J Reprod Contracept Obstet Gynecol 2015;4:398-401. 